\title{
Introduction of Eucalyptus spp. into the United States with Special Emphasis on the Southern United States
}

\author{
R. C. Kellison, ${ }^{1}$ Russ Lea, ${ }^{1,2}$ and Paul Marsh ${ }^{3}$ \\ ${ }^{1}$ North Carolina State University, Raleigh, NC, USA \\ ${ }^{2}$ CEO NEON, Inc., Boulder, CO, USA \\ ${ }^{3} 1433$ Lutz Avenue, Raleigh, NC 27607, USA \\ Correspondence should be addressed to R. C. Kellison; bkelliso@bellsouth.net
}

Received 18 May 2012; Revised 26 September 2012; Accepted 22 October 2012

Academic Editor: John Stanturf

Copyright (C) 2013 R. C. Kellison et al. This is an open access article distributed under the Creative Commons Attribution License, which permits unrestricted use, distribution, and reproduction in any medium, provided the original work is properly cited.

\begin{abstract}
Introduction of Eucalyptus spp. into the United States from Australia on a significant scale resulted from the gold rush into California in 1849. Numerous species were evaluated for fuel, wood products, and amenity purposes. The first recorded entry of eucalyptus into the southern United Stated was in 1878. Subsequent performance of selected species for ornamental purposes caused forest industry to visualize plantations for fiber production. That interest led the Florida Forestry Foundation to initiate species-introduction trials in 1959. The results were sufficiently promising that a contingent of forest products companies formed a cooperative to work with the USDA Forest Service, Lehigh Acres, FL, USA, on genetic improvement of selected species for fiber production. The Florida initiative caused other industrial forestry companies in the upper South to establish plantations regardless of the species or seed source. The result was invariably the same: failure. Bruce Zobel, Professor of Forestry, North Carolina State University, initiated a concerted effort to assess the potential worth of eucalyptus for plantation use. The joint industrial effort evaluated 569 sources representing 103 species over a 14-year period. The three levels of testing, screening, in-depth, and semioperational trials led to identification of some species and sources that offered promise for adaptation, but severe winter temperatures in late 1983 and early 1984 and 1985 terminated the project. Despite the failed attempt valuable silvicultural practices were ascertained that will be beneficial to other researchers and practitioners when attempts are again made to introduce the species complex into the US South.
\end{abstract}

\section{Introduction}

More than 500 Eucalyptus spp. (Myrtaceae) are indigenous to Australia and the bordering islands of Polynesia [1]. They occur in environments from $10^{\circ} \mathrm{N}$ to $44^{\circ} \mathrm{S}$ latitude (Mindanao Island, Philippines through Tasmania, Australia), from sea level to 2000 meters elevation (snow line) and from 10 (Northern Territory, Australia) to 375 centimeters of rainfall (Papua New Guinea). These vast differences in climate have allowed a great diversity to develop within the Eucalyptus genus. The inherent diversity has resulted in successful introduction of many of the species, for landscape, fuelwood and timber purposes, to areas within the tropical, subtropical, and warm temperate zones of the world [2].

As with other plants and animals, introduction of eucalypts to areas of the world where they are not indigenous sometimes allows for performance that is greatly superior to that exhibited in their native habitat. Reasons for the differences in performance include favorable climatic and edaphic conditions and the general lack of pests in the new environment. Notable examples of successful species introductions include E. grandis, E. urophylla, and their hybrid (Brazil, Colombia, Venezuela, Republic of Congo, Zimbabwe, South Africa), E. globulus (Chile, Portugal, Spain, southern California (USA)), E. camaldulensis (Israel, Nigeria, Morocco, India, Northern California (USA)), and E. viminalis (Argentina, Brazil, Georgia (formerly part of USSR)) [2].

Long before the species generated so much enthusiasm for plantation forestry in parts of the world, other than North America, attempts were made to introduce selected species into California. The occasion was the gold rush of 1849 . The influx of a half million people resulted in a shortage of foodstuff and supplies essential for survival and development (http://ceres.ca.gov/ceres/calweb/geology/goldrush.html). 


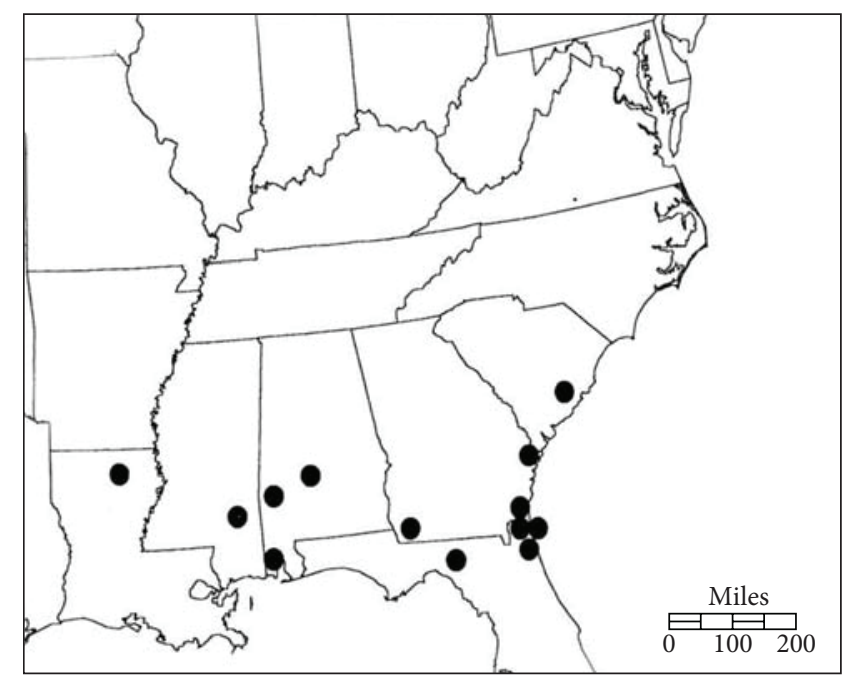

FIgURE 1: Locations for Hardwood Research Cooperative's eucalyptus evaluation trials.

This being the time before completion of the transcontinental railroad with its terminus in California [3] trade was established with offshore countries, especially Australia, New Zealand, and Chile. Wheat (Triticum spp.) for the making of flour was high on the list of imports. Schooners were soon plying the waters between domestic and foreign ports for the exchange of goods and services [4]. That trade ostensibly allowed for the exchange of seeds from forest tree species, which eventually accounted for extensive plantations of Monterey pine (Pinus radiata) in the three countries and for the introduction of eucalyptus species into California as well as into other parts of the world.

Interest in eucalyptus wood in California resulted from observations that the schooners from Australia were far superior to those manufactured from native wood in the United States. Inquiry about the wood source identified blue gum (E. globulus) as the favored species. That resulted in test planting of blue gum and other eucalyptus species from seedlings provided by the Golden Gate Nursery in San Francisco as early as 1853 [5]. The performance of a selected lot of those species so impressed landowners and wood users that additional nurseries joined the fray. By 1870, the State Board of Agriculture was espousing the need for artificial forests, with special emphasis on eucalyptus to cover areas of barren terrain and to produce wood for the manufacture of wagons, carriages, and agriculture implements. A few years later the Central Pacific Railroad was championing the need for eucalyptus timber for railroad ties. Furniture manufacturers visualized the added source of wood for their needs. Others envisioned the resource for desirable urban shade trees, markets for ointments and scented products from the processing of the odiferous eucalyptus leaves, and honey from bee pollination of the nectar-rich flowers [6, 7].

The State Board of Forestry became involved in the eucalyptus introduction program by 1887 . That organization established experiment stations at six locations (Santa Monica, Chico, Merced, Hesperia, San Jacinto, and Lake Hemet) within the state. The primary purpose of the stations
TABLE 1

\begin{tabular}{lc}
\hline Code & Cold damage \\
\hline 0 & Destroyed \\
1 & $0-25 \%$ crown functional \\
2 & $25-50 \%$ crown functional \\
3 & $50-75 \%$ crown functional \\
4 & Greater than $75 \%$ crown functional \\
5 & Functionally undamaged \\
9 & Missing or dead before freeze \\
\hline
\end{tabular}

was to urge landowners in the respective areas to establish plantations of selected eucalyptus species. A few years later the State Board of Forestry was disbanded and the experiment stations and related activities became the responsibility of the College of Agriculture, University of California at Berkeley [5]. Planting of eucalyptus for its many potential uses resulted in a major expansion program during the 1905-1912 era. The residuals of that program are the large trees that are today scattered across the landscape of the Golden State.

As with any new venture with promises, the ills of Pandora's Box came slithering out. And so it was with the wonders of eucalyptus. The railroad companies learned that the ties made from eucalyptus wood were unacceptable because the spikes needed for holding the rails in place lost their grip. Similarly the furniture manufacturers and ship builders found that instability of the fast-growing timber was a bane to their needs. Even others visualized environmental constraints on the landscape from the escape of the "noxious weed" (http://www.columbia.edu/itc/cerc/danoff-burg/ invasion_bio/inv_spp_summ/Eucalyptus_globulus.html), depletion of soil nutrients and ground water, and housing of insects and diseases that would be detrimental to native forests. Those limitations, both real and imagined, largely resulted in a hiatus of eucalyptus plantations for decades [5].

With the advent of new forest products and energy needs, interest was renewed in the introduction of eucalyptus species 
TABLE 2: Sample output from the simulator of the North Carolina State University Hardwood Cooperative eucalypts seed source evaluation program at 24 months from planting.

\begin{tabular}{|c|c|c|c|c|c|c|c|c|c|c|c|}
\hline \multirow{2}{*}{ Seed source ${ }^{\mathrm{a}}$} & \multicolumn{2}{|c|}{ Survival (\%) } & \multicolumn{2}{|c|}{ Height (ft.) } & \multicolumn{2}{|c|}{ DBH (in.) } & \multicolumn{2}{|c|}{ Cold-hardiness } & \multicolumn{2}{|c|}{ Bole form $^{b}$} & \multirow{2}{*}{ Index score } \\
\hline & Mean \% & Std. err. & Mean & Std. err. & Mean & Std. err. & Mean & Std. err. & Mean & Std. err. & \\
\hline DAL008 & 30 & 0.01 & 12.3 & 0.09 & 1.6 & 0.02 & 66 & 1.46 & 3.1 & 0.04 & 44.2 \\
\hline MAC017 & 30 & 0.01 & 9.1 & 0.08 & 0.9 & 0.01 & 58 & 1.22 & 4.0 & 0.04 & 40.6 \\
\hline DAL007 & 30 & 0.01 & 7.2 & 0.08 & 0.6 & 0.01 & 47 & 1.05 & 2.1 & 0.05 & 34.7 \\
\hline RUB003 & 30 & 0.01 & 6.3 & 0.04 & 0.4 & 0.01 & 49 & 1.77 & 2.8 & 0.06 & 34.6 \\
\hline CAP014 & 30 & 0.01 & 4.5 & 0.04 & 0.2 & 0.01 & 69 & 1.41 & 3.2 & 0.04 & 33.2 \\
\hline VIM078 & 30 & 0.01 & 5.6 & 0.38 & 0.5 & 0.02 & 49 & 3.47 & 2.7 & 0.19 & 31.8 \\
\hline BRI001 & 30 & 0.01 & 5.2 & 0.05 & 0.4 & 0.01 & 51 & 1.69 & 1.8 & 0.05 & 30.5 \\
\hline RUB004 & 30 & 0.01 & 4.8 & 0.84 & 0.7 & 0.02 & 21 & 4.82 & 1.0 & 0.19 & 26.5 \\
\hline
\end{tabular}

See Table 7 for species code.

${ }^{\mathrm{b}}$ Based on a score of 0 to 5 with the higher score being more desirable.

${ }^{\mathrm{c}}$ Higher score being more desirable.

TABLE 3: Comparison of actual versus predicted development-age 6 months.

\begin{tabular}{lcccc}
\hline \multirow{2}{*}{ Seed source } & \multicolumn{2}{c}{ Survival (\%) } & \multicolumn{2}{c}{ Mean height $(\mathrm{m})$} \\
& Actual & Predicted & Actual & Predicted \\
\hline VIM078 & 84 & 85 & 0.97 & 0.60 \\
DAL008 & 93 & 91 & 1.09 & 0.77 \\
NOV012 & 86 & 91 & 0.65 & 0.49 \\
MAC017 & 87 & 77 & 0.73 & 0.69 \\
BRI001 & 89 & 79 & 0.69 & 0.49 \\
DAL007 & 90 & 89 & 0.57 & 0.57 \\
RUB004 & 89 & 80 & 0.73 & 0.77 \\
CAP014 & 71 & 87 & 0.57 & 0.40 \\
RUB003 & 77 & 84 & 0.65 & 0.57 \\
\hline
\end{tabular}

TABLE 4: Comparison of actual versus predicted development-age 12 months.

\begin{tabular}{lcccc}
\hline \multirow{2}{*}{ Seed source } & \multicolumn{2}{c}{ Survival (\%) } & \multicolumn{2}{c}{ Mean height $(\mathrm{m})$} \\
& Actual & Predicted & Actual & Predicted \\
\hline DAL008 & 72 & 72 & 1.98 & 1.86 \\
NOV012 & 67 & 72 & 0.97 & 1.25 \\
VIM078 & 62 & 60 & 0.73 & 1.21 \\
MAC017 & 32 & 48 & 1.66 & 1.54 \\
BRI001 & 53 & 49 & 0.93 & 0.97 \\
DAL007 & 56 & 67 & 1.38 & 1.26 \\
RUB003 & 54 & 56 & 0.89 & 1.17 \\
RUB004 & 38 & 45 & 1.13 & 1.50 \\
CAP014 & 58 & 64 & 0.73 & 0.85 \\
\hline
\end{tabular}

into California after a lapse of nearly half a century. One such event was in the 1950s and 1960s when fiberboard became a commodity in home construction and furniture manufacture. The second event resulted from the oil embargo instituted by the Organization of Petroleum Exporting Countries (OPEC) in the late 1970s [5]. Both of these events proved to be a "flash in the pan." The first one was exposed when it was learned that the manufactured board could be made from
TABLE 5: Comparison of actual versus predicted development-age 24 months.

\begin{tabular}{lcccc}
\hline \multirow{2}{*}{ Seed source } & \multicolumn{2}{c}{ Survival (\%) } & \multicolumn{2}{c}{ Mean height $(\mathrm{m})$} \\
& Actual & Predicted & Actual & Predicted \\
\hline VIM078 & 45 & 42 & 2.23 & 2.31 \\
DAL008 & 45 & 48 & 4.17 & 4.66 \\
NOV012 & 58 & 47 & 2.96 & 3.40 \\
MAC017 & 46 & 38 & 2.79 & 3.44 \\
BRI001 & 38 & 33 & 2.02 & 2.02 \\
DAL007 & 36 & 36 & 2.59 & 2.75 \\
RUB004 & 6 & 7 & 2.55 & 2.71 \\
CAP014 & 51 & 42 & 1.62 & 1.74 \\
RUB003 & 27 & 23 & 2.19 & 2.43 \\
\hline
\end{tabular}

TABLE 6

\begin{tabular}{lc}
\hline Source & CSIRO Seed lot no. \\
\hline VIM 077 & 9217 \\
VIM 069 & 8978 \\
VIM 063 & 10726 \\
VIM 061 & 10836 \\
VIM 113 & 11978 \\
CAP 013 & 5317 \\
DAL 008 & 8847 \\
MAC 010 & S10942 \\
MAC 016 & 12084 \\
\hline
\end{tabular}

wood residue from other manufacturing processes, and the second one took its leave when oil became readily available at relatively low prices. Due to the volatile conditions in the Middle East and the relatively high price of crude oil another effort to grow eucalyptus was undertaken in California in the 1990s, but the effort came with financial and environmental scrutiny. The complications proved greater than the benefits [5]. 
TABLE 7: Eucalyptus seed lots tested by species and number of installation in the Lower Coastal Plain of the US South by members of the Hardwood Research Cooperative.

\begin{tabular}{|c|c|c|c|}
\hline Species code & Species name & $\begin{array}{c}\text { No. of } \\
\text { installations } \\
\text { by species }\end{array}$ & $\begin{array}{l}\text { No. of seed } \\
\text { lots tested }\end{array}$ \\
\hline$\overline{\mathrm{AGL}}$ & AGGLOMERATA & 5 & 12 \\
\hline AGR & AGGREGATA & 1 & 1 \\
\hline ALP & ALPINA & 2 & 2 \\
\hline AMP & AMPFOLIA & 4 & 12 \\
\hline AND & ANDREWSII & 2 & 2 \\
\hline BAD & BADJENSIS & 5 & 11 \\
\hline BAN & BANCROFTII & 0 & 0 \\
\hline $\mathrm{BIC}$ & BICOSTATA & 7 & 29 \\
\hline BLA & BLAKELYI & 4 & 14 \\
\hline BOT & BOTRYOIDES & 2 & 9 \\
\hline BRI & BRIDGESIANA & 2 & 13 \\
\hline CAA & CAMPANULATA & 4 & 6 \\
\hline CAE & CAMERONII & 1 & 1 \\
\hline CAL & CALIGINOSA & 2 & 2 \\
\hline CAM & CAMALDULENSIS & 7 & 17 \\
\hline CAP & CAMPHORA & 17 & 68 \\
\hline $\mathrm{CHA}$ & CHAPMANIANA & 3 & 5 \\
\hline $\mathrm{CIN}$ & CINEREA & 5 & 24 \\
\hline CIT & CITRIODORA & 1 & 1 \\
\hline $\mathrm{COC}$ & COCCIFERA & 2 & 2 \\
\hline COR & CORDATA & 0 & 0 \\
\hline CRE & CRENULATA & 3 & 16 \\
\hline CYP & CYPELLOCARPA & 5 & 16 \\
\hline DAL & DALRYMPLEANA & 33 & 63 \\
\hline DEA & DEANEI & 2 & 12 \\
\hline DEB & DEBEUZEVILLEI & 2 & 2 \\
\hline DEL & DELEGATENSIS & 10 & 15 \\
\hline DIR & DIVERSICOLOR & 0 & 0 \\
\hline DIV & DIVES & 2 & 2 \\
\hline DRX & DELEGATENSIS X & 1 & 1 \\
\hline DUN & DUNNII & 3 & 15 \\
\hline ELA & ELATA & 2 & 2 \\
\hline EUG & EUGENIODES & 2 & 4 \\
\hline EXP & EXPELLACARPA & 1 & 1 \\
\hline FAS & FASTIGATA & 4 & 7 \\
\hline FRA & FRAXINOIDES & 4 & 6 \\
\hline GLA & GLAUCESCENS & 3 & 11 \\
\hline GLO & GLOBULUS & 1 & 3 \\
\hline GRA & GRANDIS & 1 & 1 \\
\hline GUN & GUNNII & 2 & 7 \\
\hline $\mathrm{JOH}$ & JONSTONII & 4 & 10 \\
\hline KAR & KARTZOFFIANA & 1 & 5 \\
\hline KYB & KYBEANENSIS & 1 & 1 \\
\hline LAE & LAEVOPINEA & 4 & 4 \\
\hline LEU & LEUCOXYLON & 2 & 3 \\
\hline
\end{tabular}

TABLE 7: Continued.

\begin{tabular}{|c|c|c|c|}
\hline Species code & Species name & $\begin{array}{c}\text { No. of } \\
\text { installations } \\
\text { by species }\end{array}$ & $\begin{array}{l}\text { No. of seed } \\
\text { lots tested }\end{array}$ \\
\hline MAC & MACARTHURII & 22 & 90 \\
\hline MAI & MAIDENII & 0 & 0 \\
\hline MAL & MALACOXYLON & 1 & 2 \\
\hline MAN & MANNIFERA & 1 & 6 \\
\hline MAR & MACRORHYNCHA & 1 & 1 \\
\hline MAT & MARGINATA & 0 & 0 \\
\hline MEL & MELLIODORA & 3 & 11 \\
\hline MIC & MICROCORYS & 2 & 6 \\
\hline MIT & MITCHELLIANA & 2 & 3 \\
\hline MOO & MOOREI & 1 & 1 \\
\hline MOR & MORRISBYI & 2 & 2 \\
\hline MUL & MULLERIANA & 1 & 1 \\
\hline NEG & NEGLECTA & 2 & 4 \\
\hline NIP & NIPHOPHILIA & 1 & 1 \\
\hline NIT & NITENS & 40 & 154 \\
\hline $\mathrm{NOV}$ & NOVA-ANGLICA & 14 & 57 \\
\hline NTD & NITIDA & 0 & 0 \\
\hline NUM & NUMEROSA & 0 & 0 \\
\hline NVX & NOVA-ANGLICA X & 2 & 3 \\
\hline OBL & OBLIQUA & 4 & 4 \\
\hline ORE & OREADEA & 5 & 7 \\
\hline OVA & OVATA & 8 & 23 \\
\hline PAL & PALIFORMIS & 1 & 1 \\
\hline PAR & PARVIFOLIA & 4 & 12 \\
\hline PAU & PAUCIFLORA & 3 & 3 \\
\hline PER & PERRINIANA & 4 & 9 \\
\hline PIL & PILULARIS & 1 & 1 \\
\hline PIP & PIPERITA & 2 & 2 \\
\hline POL & POLVERULENTA & 0 & 0 \\
\hline POY & POLYANTHEMOS & 2 & 7 \\
\hline PSE & PSEUDOGLOBULUS & 1 & 1 \\
\hline PUL & PULCHELLA & 1 & 1 \\
\hline PUV & PULVERULENTA & 3 & 18 \\
\hline QUA & QUADRANGULATA & 1 & 4 \\
\hline RAD & RADIATA & 5 & 7 \\
\hline REG & REGNANS & 6 & 6 \\
\hline RES & RESINIFERA & 0 & 0 \\
\hline RIS & RISDONII & 1 & 1 \\
\hline ROB & ROBERTSONII & 2 & 2 \\
\hline ROD & RODWAYII & 1 & 3 \\
\hline ROS & ROSSII & 2 & 2 \\
\hline ROU & ROBUSTA & 1 & 1 \\
\hline RUB & RUBIDA & 3 & 15 \\
\hline SAL & SALIGNA & 1 & 5 \\
\hline SIB & SIEBERIANA & 0 & 0 \\
\hline
\end{tabular}


TABLE 7: Continued.

\begin{tabular}{lccc}
\hline Species code & Species name & $\begin{array}{c}\text { No. of } \\
\text { installations } \\
\text { by species }\end{array}$ & $\begin{array}{c}\text { No. of seed } \\
\text { lots tested }\end{array}$ \\
\hline SID & SIDEROXYLON & 2 & 4 \\
SIE & SIEBERI & 2 & 2 \\
SMI & SMITHII & 3 & 10 \\
STE & STELLULATA & 1 & 3 \\
STJ & ST JOHNII & 1 & 1 \\
STN & STENOSTOMA & 2 & 3 \\
TEN & TENUIRAMIS & 1 & 1 \\
TER & TERETICORMIS & 4 & 16 \\
UNK & UNKNOWN & 1 & 1 \\
URN & URNIGERA & 3 & 14 \\
URO & UROPHYLLA & 1 & 7 \\
VIM & VIMINALIS & 134 & 575 \\
YOU & YOUMANII & 1 & 2 \\
\hline
\end{tabular}

\section{Historical Perspective of Eucalyptus Introduction to the South}

The outstanding performance of eucalyptus in some of the exotic environments in offshore countries has often impressed foresters and their superiors from the warm temperate zones of the southern United States. The logic was that the growth rate of the eucalyptus would be far superior to that of indigenous plantations hardwoods of cottonwood (Populus deltoides), sweetgum (Liquidambar styraciflua), sycamore (Platanus occidentalis), and other species. The added impetus for the introduction of eucalyptus for plantation use is the excellent wood properties (high fiber count) of the myriad species for pulp and paper manufacture [8].

Species of eucalyptus were introduced to the South as early as 1878 [9], but no significant commercial plantations were established through the first half of the 20th century. Even though forest-based organizations such as St. Regis Paper Company and Champion International Corporation trial planted eucalyptus in Florida and Texas, respectively, in the 1950s and 1960s, most plantings before 1970 were of small scale for windbreaks, ornamentals, and shade trees in central and Southern Florida and Texas [10].

In 1959, the Florida Forests Foundation initiated research on eucalyptus as a potential source of hardwood pulpwood on rangeland and other low-quality sites in the area generally south of Tampa, Florida. Their research was absorbed by the USDA Forest Service and the Florida Division of Forestry in 1968. In the early 1970s, a eucalypts research cooperative was formed by Buckeye Cellulose Corporation, Brunswick Pulp Land Company, Container Corporation of America, Hudson Pulp and Paper Company, ITT Rayonier and St. Regis Paper Company, in conjunction with Lykes Brothers Land Company, to provide financial and research support to the USDA Forest Service scientists at Lehigh Acres, Florida [9]. This effort led to the selection of E. grandis,
E. robusta, E. camaldulensis, and E. tereticornis and to the development of cultural practices by which to raise seedlings and establish commercial plantations over parts of South Florida. A significant part of this effort was four phases of genetic improvement of E. grandis by Dr. Carlyle Franklin and Mr. George Meskimen of the USDA Forest Service, and to lesser levels of genetic improvement of other species [9].

\section{North Carolina State University Hardwood Research Cooperative Becomes Involved}

In the 1950s and 1960s several southern forest-based companies other than Champion and St. Regis tried to introduce eucalyptus for plantation use. The scenario followed a similar line: a newly appointed vice president would become infatuated with the performance of eucalyptus in an exotic environment such as Brazil. The ensuing directive was to plant eucalyptus seedlings on company land, often in the hundreds of acres. The lack of adaptation of the exotic species was invariably the same: failure. The event became so repeatable that it was labeled the "seven-year silly cycle." The seven-year cycle spanned the approximate time before one vice president succeeded another.

By 1971, Bruce Zobel and others at the North Carolina State University decided to evaluate the introduction of eucalyptus into the southern US on a scientific manner. Working with company members of the Hardwood Research Cooperative, the plan was to systematically evaluate eucalyptus species and sources to determine their adaptability [11]. By 1978, the industrial members of the Florida group united with the Hardwood Cooperative in pursuit of the goal. The eucalyptus dream was pursued until 1985 when the 14-year effort came to an end, following severe freezes on December 24, 1983, January 20, 1984, and January 9, 1985.

\section{Purpose of This Report}

The initial purpose of this report was to provide a record of the species and sources that were evaluated, method of evaluation, location of the tests, cause of failure, and recommendations for subsequent research on eucalypts for use in southern forestry. The rationale was that, with time, people involved in the project would have forgotten the particulars, and for their successors to be unaware that such an exhaustive effort ever took place. To repeat an adage: "Those that ignore the past are condemned to repeat it."

\section{The Method}

During the 14-year period, 569 eucalyptus seed sources representing 103 species (Table 7) were planted in 141 different tests throughout the southern USA The general geographic locations of the study sites are depicted in Figure 1.

The seed material was obtained from the indigenous range of the species in Australia and neighboring islands as well as from exotic plantations. The emphasis on obtaining seeds from exotic plantations outside of Australia was because of the supposition that there would have been 
a genetic selection for adaptability to foreign sites. In addition, the International Paper Company deployed Research Forester Ron Hunt to Australia to collaborate with the Tree Seed Centre of the Commonwealth Scientific and Industrial Research Organization (CSIRO) in making seed collections of eucalyptus species that appeared to have good potential for the southern United States [11]. The Hardwood Research Cooperative served as the clearing house for the distribution of seeds and plant material to cooperators, for plot design, and for collection and analysis of data from test plantings.

To evaluate the material, 3 types of tests were installed: (1) screening trials that consisted of 6-tree row plots replicated 6 times, (2) in-depth trials that consisted of 4 replications of 25tree plots of the most promising species/sources identified in the screening trials, and (3) semioperational trials of 0.4 to 2 hectares that consisted of the most promising species/sources identified in the in-depth trials.

All new seed lots were exposed to the screening trial, at two or more locations (sometimes as many as eight) depending upon the amount of seed available. The initial trials were installed from North Carolina, Tennessee, and Arkansas southward. It soon became evident, however, that the harsher winters in the northern tier of the southern states left no room for selection at the species, source, or tree level because all plants were badly damaged or killed by freezing temperatures. The decision was then made to restrict trial plantings to the USDA Plant Hardiness Zone VIII and higher (http://www.usna.usda.gov/Hardzone/ushzmap.html), which encompasses an area from Charleston, SC, southward along the coast to Savannah, GA, thence westward along the upper fringes of the Lower Coastal Plain through Georgia, Alabama, Mississippi, Louisiana, and into East Texas.

5.1. Screening Trials. Evaluation of the screening trials was performed after the first growing season, to determine survival and potential growth before the onset of winter. A second evaluation was made at about the time of bud break in the spring of the second growing season which allowed for assessment of cold damage incurred during the winter. The third assessment was made at the beginning of the third growing season. The only data recorded at these measurement periods were tree height and survival. A subjective judgment was made on cold tolerance. Any source exhibiting acceptable performance levels for these two traits and being relatively free of cold damage was designated for "in-depth" planting. Most screening trials were abandoned after the second growing season since the seed sources with below-average survival and cold tolerance would not significantly change rank after two growing seasons. Survival rates, inclusive of cold damage, from the screening trials were low: over $80 \%$ of the sources had lower than 40 percent survival at the end of two years. The remaining 113 sources were advanced to the in-depth trials.

5.2. In-Depth Trials. The 25-tree square plot design used for the in-depth trials allowed assessment of the 16 interior trees without interference from the adjacent plot of trees of a separate source. These replicated trials were installed at two to eight locations, depending upon the availability of seeds and seedlings.

In similar fashion as that described for the screening trials, the first measurements from the in-depth trials were of height and survival at the end of the first growing season. Cold damage was assessed at the beginning of the following growing season and every two years thereafter until the end of the study, using the scale in Table 1.

In addition to survival, total height, and cold tolerance, measurements were made of diameter at breast height, and bole form was subjectively ranked.

Some of the species and sources were extremely susceptible to the swings in winter temperatures and were killed during the first growing season. Others, however, were little affected by the fluctuating temperatures for the first several years. The species with initial cold tolerance nearly always exhibited a slower growth and poorer form than did those most susceptible to freezing temperatures. One such species was the E. camphora. Other species and sources, however, such as E. viminalis, E. macarthurii, and E. nova-anglica were highly variable in their performance. Some showed a good growth and form along with a good cold tolerance. Others with a good growth and form were very susceptible to freezing temperatures, and still others showed combinations of these traits. It was these lots that commanded attention because the opportunity ostensibly existed to select and breed for the desired traits.

Analysis of the data proved difficult because none of the 569 seed sources were planted on more than 20 percent of the sites and no site had more than 16 percent of the sources. This limitation arose because of the need to distribute the work load among cooperators; thus, the consignment of 20 seed lots, for example, going to Cooperator A for trial establishment was often very different from those going to Cooperator B. The rather complicated statistical analysis that was developed to make comparisons consisted of three parts: (1) using statistical regression, predictive equations were formulated for each of the measured variables, (2) a linear composite of these variables was created that permitted comparison of the seed sources over locations and time, and (3) a multivariate computer simulation, involving the predictive estimators, was used to compute the mean and variance of the linear composite for each source at each location. The simulator allowed an index score for a species/source to be determined across locations (Table 2).

The simulator was validated by comparing the actual survival and mean height of a specific species/source in a specific test to its predicted value. Tables 3,4 and 5 show these values for nine of the species/sources at 6,12 , and 24 months. In the absence of cold damage or other unexpected events, the simulator could predict with confidence the species/sources that had the greatest potential for plantation use in the southern United States.

Since the severe freezes of 1983, 1984, and 1985 killed or damaged the plant material beyond salvage, the results of the statistical analyses are moot and therefore will be omitted. 
5.3. Semioperational Trials. An analysis of the in-depth trials helped to identify nine sources of eucalyptus that were superior in performance to all the other sources evaluated. (ses Table 6).

These sources were planted in 10 demonstration trials across the South in 1981 but were severely damaged or killed by the severe freezes of December 24, 1983, January 20, 1984, and January 9, 1985. This list is different from the one issued in 1978 in which Hunt and Zobel [11] identified E. viminalis, E. nova-anglica, E. macarthurii, and E. camphora as the most promising species. The difference between the two lists is that the present one is the result of statistical analysis whereas the former one was based on observation. Again, the difference is moot because all species, regardless of the method of selection, were equally vulnerable to the severe freezes of 1983 to 1985 .

\section{Lessons Learned}

Among the lessons learned from the 14 years of testing of eucalypts for use in the southern United States are the following.

6.1. Eucalyptus Have Indeterminate Growth. No amount of field testing will identify a species or source that will have a universal adaptability to the fluctuating winter temperatures in the southern United States. The reason is that Eucalyptus spp. have an indeterminate type of growth that results from their naked buds [2]. As opposed to indigenous species of cottonwood, sweetgum, sycamore, loblolly pine (Pinus taeda), and so forth that have covered buds, eucalyptus begins cell division during the winter whenever the ambient nighttime air temperature exceeds $6^{\circ} \mathrm{C}$ for six consecutive days. A sudden drop in temperature to near the freezing point during such an event is enough to cause freeze damage to the active tissue. The indigenous species, with their covered buds, do not begin cell activity under such circumstances until a combination of temperature and photoperiod trigger the cambial activity.

6.2. Variation in Cold Tolerance. A considerable variation in cold tolerance exists within every species and source of eucalyptus. Among those with greatest cold tolerance, the opportunity exists to select the trees most resistant to freeze damage and to breed for increased tolerance Meskimen and Franklin [12]. Progress was made during our 14 years of trial and error with $E$. viminalis, whereby the best trees for cold tolerance, growth, and form were selected for inclusion in a proposed clonal seed orchard at Fort Green Springs, Florida, on lands of the Container Corporation of America. The concept was to interbreed the selected trees and subject their progeny to freezing temperatures from which the survivors would again be selected for their tolerance to cold. This procedure was to be repeated until a genetic line with the desired traits would be available for plantation use.

The weakness of the plan was that E. viminalis and the other most promising species for the Florida environment flowered in February, much as they do in their native habitat.
Even at the southerly location of central Florida, seed set was scanty at best and usually nonexistent because the flowers were susceptible to winter frosts. A further limitation to viable seed set was the hibernation of pollinating insects, especially honeybees, during that season of the year.

To overcome these limitations, consideration was given to vegetatively propagating the selected trees for shipment to a frost-free environment in South America. Cooperation with Carton de Colombia and Carton de Venezuela, sister companies of the Container Corporation of America was considered. The concept was to produce seeds from intercrossing the selections in the foreign environment and to screen the seedlings for cold tolerance in the Northern Hemisphere. Graduate Assistant Michael Cunningham of North Carolina State University, with funding from the USDA Forest Service and Container Corporation of America, was successful in cloning the selections by tissue culture [13], but the severe freezes of the mid-1980s destroyed the last vestiges of the project.

6.3. Soil Suitability. Planting trials were established on the variety of soil conditions in the Lower Coastal Plain, from sand ridges to imperfectly drained soils. The best performance was obtained on sandy loam soils with a rooting depth of 45 to 90 centimeters. Imperfectly drained soils, inclusive of bedding, were poorly suited to acceptable performance of eucalypts after about two growing seasons. Similarly, the excessively drained soils proved inopportune because of nutrient and moisture deficiency [8].

6.4. Containerized versus Bareroot Seedlings. The initial trials were installed exclusively with containerized seedlings. Wellbalanced seedlings with a root-shoot ratio of about 0.6 gave superior results. Containerized seedlings can be planted with good results any time during the growing season if there is sufficient soil moisture. Later studies, conducted by the International Paper Company and Brunswick Pulp Land Company, showed that bareroot seedlings performed equally as well or better than the containerized ones if the seedlings were planted immediately after being lifted from the nursery bed after the last spring frost [2].

6.5. Weed Competition. Eucalyptus species do not tolerate weed competition, either for sunlight or below ground resources during their first two years after planting. The lack of efficacious and safe silvichemicals during the period of the early trials made competition control a difficult challenge. Cold tolerance of adapted eucalypts is positively correlated with vigor. Trees that are stressed by weed competition or lack of nutrients are more susceptible to freeze damage than those without the limitations $[14,15]$.

6.6. Response to Added Nutrients. Eucalypt seedlings responded to added nutrients, especially nitrogen, in every trial in which fertilizers were added [16]. Soils with phosphorus deficiency showed that plant growth declined as soon as the second year after planting. Potassium and magnesium deficiencies were also observed at some of the 
planting sites. Best responses were obtained from soils of $\mathrm{pH}$ 5.5 to $6.0[14]$.

6.7. Tree Spacing. Spacing for the test plantings was $3.5 \times$ $3.2 \mathrm{~m}$. For test purposes this spacing was sufficient, but observations from commercial plantations in Brazil, South Africa, and elsewhere suggest that tree spacing of $4 \times 4 \mathrm{~m}$ or something similar is required for rotations longer than 8 to 10 years. Because nearly all eucalyptus species are intolerant of overlapping crowns, thinning is required for optimum growth of closely spaced trees for rotations longer than 10 years $[8,17]$.

6.8. Greenhouse Studies for Cold Tolerance Poorly Correlated to Field Studies. Results from cold tolerance studies, conducted in greenhouses and phytotrons, were poorly correlated to field studies because of the highly variable performance of eucalyptus in the experimental plantings across the South [18]. Some species/sources were subject to the first winter freezes, whereas others performed well for a number of years before the combination of variables developed to damage or kill the trees. Freezing temperatures in combination with frigid chill factors had a particularly devastating effect. In 1978 , for example, an uncommonly heavy snow of $60 \mathrm{~cm}$ that blanketed the Eastern Seaboard resulted in the death of the plant material extending above the snow line. Foliage below the line survived without damage because of the insulation effect of snow.

6.9. Performance Modeling Failed. Performance modeling of the best species/source has proven to be an impossible task because a combination of factors would prove fatal to the trees in one year and a separate set of factors would prove equally as destructive in another year. High hopes were generated for the success of the project when certain trees, especially of E. viminalis, would escape the ravages of winter in the midst of other species/sources that succumbed to the freezing temperatures. Some of those trees grew to be 25 meters tall and $25 \mathrm{~cm}$ diameter at breast height in 6 to 8 years. In a subsequent winter, however, they too would be killed, even when the temperatures were less severe than those of the previous winter.

6.10. Fluctuations in Winter Temperatures Prove Fatal. Outside of the severe freezes that occurred in 1983, 1984, and 1985 , the greatest damage always resulted when there were great fluctuations in temperature within one or two days. Temperatures in excess of $15^{\circ} \mathrm{C}$ in midwinter are occasionally followed by temperature drops of $12^{\circ} \mathrm{C}$ or more within a 24-hour period as a result of cold fronts that originate in northern latitudes and sweep through the Great Plains to the southern United States. The active cambial growth of the eucalypts, with their naked buds, is extremely vulnerable to such fluctuations. Under such circumstances, freeze damage can happen to some species/sources of eucalypts at temperatures slightly above $0^{\circ} \mathrm{C}$.
6.11. Wood Properties Prove Acceptable. Four- to six-yearold trees of $E$. viminalis produced wood with specific gravity, fiber dimensions, and pulp and paper properties similar to that of sweetgum of 15 years of age [19,20]. Fluff pulp is especially desired from eucalypts because of the high fiber to vessel ratio.

6.12. Inhospitable Environment for Plants. The southern United States is an inhospitable environment for the growing of exotic forest trees. The area has been compared with that of Siberia, without its severity, for its great fluctuations in winter temperature. This phenomenon prohibits the successful establishment of forest trees from most other parts of the world where the mean winter temperature can be even lower than that in the southern United States. The temperatures in those areas, however, decline steadily from summer highs to winter lows in the absence of fluctuating warm and cold temperatures. That is why seed sources of thriving plantations of Eucalyptus spp. from other areas of the world, such as $E$. dunnii from southern Brazil, E. deanii from France, and E. viminalis from Georgia (formerly the Soviet Union), failed when introduced to the United States.

6.13. Molecular Genetics to Aid Species Introduction. In combination with warming trends, the successful introduction of eucalypts to the southern United States will be aided by the use of molecular genetics. Work has been accomplished on the gene mapping of E. grandis, E. globulus and their hybrid by the Biotechnology Program at the North Carolina State University [12]. Quantitative trait loci (QTL) have been identified for tree growth, and speculation exists that a similar phenomenon exists for oliogenic inheritance for cold tolerance.

\section{Summary}

The outstanding performance of eucalyptus species growing in foreign countries caused industrial foresters to establish semioperational plantations in the southern United States in the 1950s and 1960s. Failure of the plantations, due primarily to cold damage, resulted in establishment of research trials across the landscape from the Atlanta Ocean to areas west of the Mississippi River. Seed sources for the trials were obtained from natural stands in Australia and from exotic plantations from much of the Tropics and Warm Temperate Zones of the world where the species were growing. Over a 14-year span, 569 seed sources, representing 103 species were evaluated for industrial use. The species/sources showing most promise in screening trials were further tested in indepth trials, and those of greatest promise in in-depth trials were subjected to semioperational trials.

Statistical analyses of the collected tree data consisted of three steps: (1) using regression and analysis, predictive equations were formulated for each of the measured variables, (2) a linear composite of these variables was created that permitted comparison of the seed sources over locations and time, and (3) a multivariate computer simulation, involving the predictive estimators, was used to compute the mean 
and variance of the linear composite for each source at each location. The simulator allowed an index score for species/sources to be determined across locations.

Regardless of the growth potential of selected species/ sources the effort came to naught because of susceptibility to severe winter temperatures in late 1983 and early 1984 and 1955. Since the initiative lost its appeal more than 25 years ago, temperatures have apparently moderated enough across the South for establishment of new introductory trials. With the experience gained from the past endeavor, we urge present-day investigators to concentrate their efforts on soils of sandy clay loam and clay loam and to avoid imperfectly drained soils and those of excessive soil drainage (high sand content). It is also highly recommended that the plantations be kept free from weed competition for at least the first two growing seasons and that attention be given to soil fertility. Seedling quality for bareroot planting should be in the range of 0.6 for root-shoot ratio, and such seedlings should be planted in early spring, but after the last frost. Containerized seedlings can be planted at any time of the year whenever there is adequate soil moisture. Fall planting of containerized seedlings must occur in time for root establishment before first frosts.

\section{Disclosure}

The basic part of this paper was written in 1985. It was never published but was committed to the files so that the results could be shared whenever there was a renewed effort to introduce eucalyptus to the U.S. South. The authors of the 27 years ago paper have revised it to coincide with today's needs as well as to shed light on the introduction of eucalyptus to California.

\section{References}

[1] Introduction to Eucalyptus. Blog posted by Phytopath, 2010.

[2] J. Davidson, "Ecological Aspects of Eucalyptus Plantations," FAO Corporate Document Repository. Proceedings of Regional Expert Consultation o Eucalyptus. Vol.1, 1979.

[3] D. H. Bain, Empire Express; Building the First Transcontinental Railroad, Viking Penguin, 1999.

[4] S. Villalobos, S. Osvaldo, S. Fernando, and E. Patricio, History de Chile. Editorial Universitaria, Chile. pp. 406-413, 1974.

[5] R. L. Santos, The Eucalyptus of California, Alley-Cass, Denair, Calif, USA, 1997.

[6] G. M. Groenendaal, “Eucalyptus helped solve a timber problem," in Proceedings of the Workshop on Eucalyptus in California, pp. 1853-1880, Sacramento, Calif, USA, 1983.

[7] R. Crawford, "The Way We Were: Eucalyptus Trees Have Deep Roots in California's History," The San Diego Union-Tribune, 2008.

[8] C. Foelkel, "The Eucalyptus fibers and the pulp quality requirements for paper manufacturing," 2007, http://www.eucalyptus.com.br/.

[9] T. F. Geary, G. F. Meskimen, and E. C. Franklin, "Growing Eucalypts in Florida for industrial wood production," Tech. Rep. SE-23, Southeastern Forest Experiment Station, USDA Forest Service, Asheville, NC, USA, 1983.
[10] R. J. Moultin, “Tree planting in the United States, 1997," Tree Planters' Notes, vol. 49, no. 1, pp. 5-15, 1999.

[11] R. Hunt and B. Zobel, "Frost-hardy Eucalyptus grow well in the Southeast," Southern Journal of Applied Forestry, vol. 2, no. 1, pp. 6-10, 1978.

[12] A. A. Myburg, A. R. Griffin, R. R. Sederoff, and R. W. Whetten, "Comparative genetic linkage maps of Eucalyptus grandis, Eucalyptus globulus and their F1 hybrid based on a double pseudo-backcross mapping approach," Theoretical and Applied Genetics, vol. 107, no. 6, pp. 1028-1042, 2003.

[13] M. Cunningham and R. Mott, "Micropropagation of Eucalyptus viminalis," in Proceedings of the Forestry Conference, p. 8, Division of Continuing Education, Louisiana State University, Baton Rouge, La, USA, 1985.

[14] G. Meskimen, "Fertilizer tablets stimulate eucalyptus in Florida trial,” 1971USDA Forest Service Research Note SE-162, Lehigh Acres, Fla, USA, 12, 1971.

[15] A. P. G. Schonau, R. Verloren von Themaat, and D. L. Boden, "The importance of complete site preparation and fertilizing in the establishment of Eucalyptus grandis," South African Journal of Forestry, vol. 116, pp. 1-10, 1981.

[16] N. F. Barros, "Some aspects of Eucalyptus fertilization: A review of current literature as a contribution to future Eucalyptus research and planting in Florida," Florida Agric. Exp. Stations, Institute of Food and Agricultural Sciences, University of Florida, Gainesville, 1977.

[17] G. Meskimen and E. C. Franklin, "Spacing Eucalyptus grandis in southern Florida: a question of merchantable versus total volume," Southern Journal of Applied Forestry, vol. 1, pp. 3-5, 1978.

[18] E. B. Schultz, Artificial cold hardiness of Eucalyptus [M.S. thesis], North Carolina State University, Raleigh, NC, USA, 1979.

[19] E. C. Franklin, "Yield and properties of pulp from eucalypt wood grown in Florida," Tappi, vol. 60, no. 6, pp. 65-67, 1977.

[20] G. O. Otegebe and R. C. Kellison, "Genetics of wood and barfk characteristics of Eucalyptus viminalis," Silva Genetica, vol. 29, no. 1, pp. 27-30, 1980. 

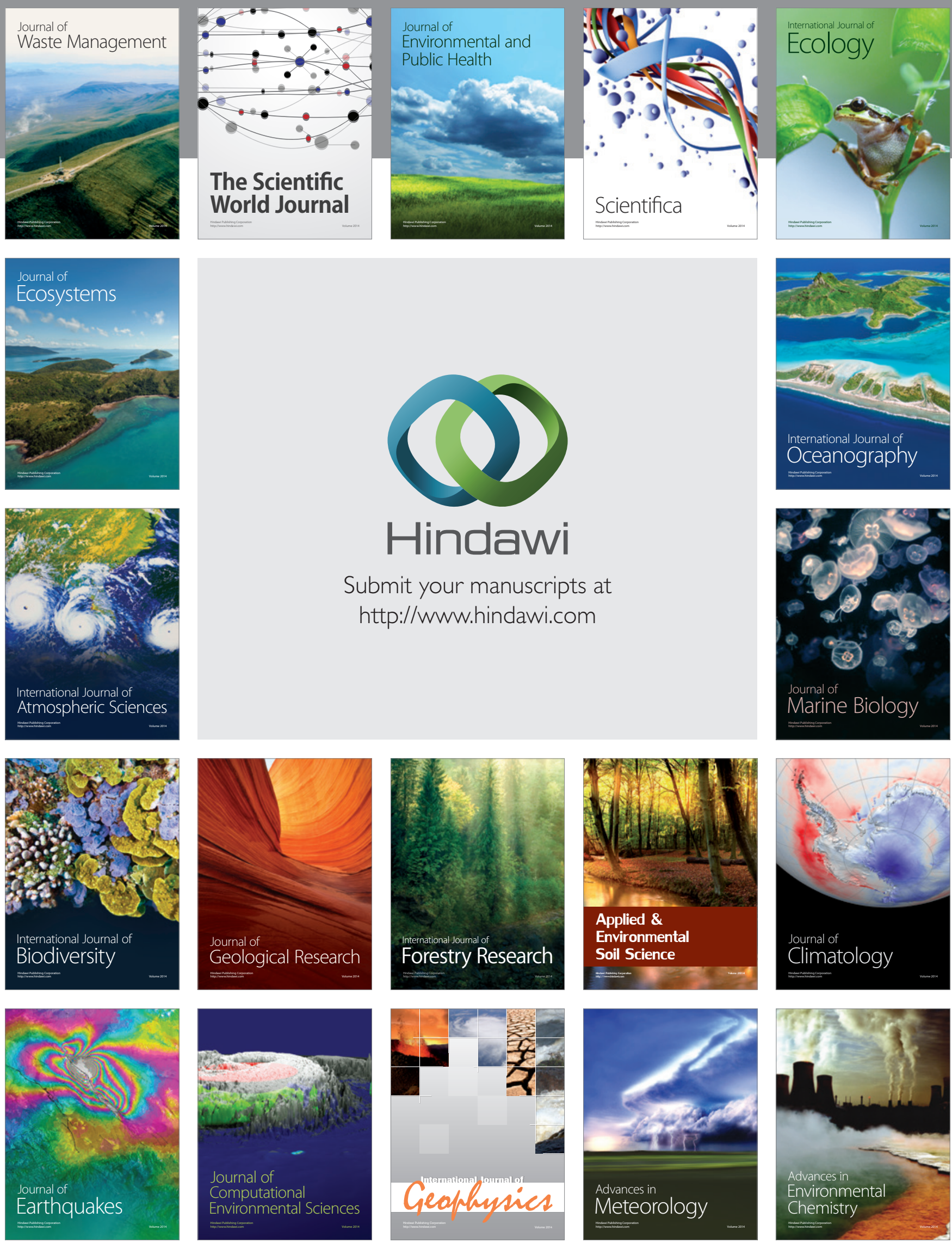